\title{
Dactylospora anziae, a new lichenicolous ascomycete on Anzia from East Asia
}

\author{
Mikhail P. Zhurbenko' ${ }^{1}$, Alexandr K. Ezhkin ${ }^{2}$, Irina F. Skirina ${ }^{3}$ \& Yoshihito Ohmura $^{4}$ \\ ${ }^{1}$ Laboratory of the Systematics and Geography of Fungi, Komarov Botanical Institute, Russian Academy of Sciences, \\ Professora Popova, 2, St. Petersburg, 197376, Russia. E-mail: zhurb58@gmail.com \\ ${ }^{2}$ Laboratory of the Coastal Ecosystems, Institute of Marine Geology and Geophysics, Far Eastern Branch of the Russian \\ Academy of Sciences, Nauki, 1B, Yuzhno-Sakhalinsk, 693022, Russia. E-mail: ezhkin@yandex.ru \\ ${ }^{3}$ Center for Landscape and Environmental Researches, Pacific Institute of Geography, Far East Branch of the Russian \\ Academy of Sciences, Radio, 7, Vladivostok, 690041, Russia. E-mail: sskirin@yandex.ru \\ ${ }^{4}$ Department of Botany, National Museum of Nature and Science, Amakubo 4-1-1, Tsukuba, Ibaraki, 305-0005, Japan. \\ E-mail: ohmura-y@kahaku.go.jp
}

Abstract: Dactylospora anziae growing on species of Anzia is described from Russia and Japan.

Keywords: new species; Russia; Japan

\section{INTRODUCTION}

Dactylospora Körb. (Dactylosporaceae) is a genus of discomycetes comprising about 50 species, mostly growing on lichens but also occurring on non-lichenized fungi, bryophytes, bark or lignum (Hafellner, 2004). Lichenicolous species of Dactylospora are known from a wide range of distantly related lichens, but have not been yet reported from Anzia (Lawrey \& Diederich, 2017). Previously, the latter genus was known to host just one species of lichenicolous fungi, Skyttea anziae Etayo \& Diederich, reported on Anzia sp. from Columbia (Etayo, 2002). The aim of this paper is to describe a new Dactylospora species found on several species of Anzia in Asian-Pacific region.

\section{MATERIAL AND METHODS}

The specimens were examined using Zeiss microscopes Stemi 2000-CS and Axio Imager A1 equipped with Nomarski differential interference contrast optics. Microscopical examination was done in water, $10 \% \mathrm{KOH}(\mathrm{K})$, Lugol's iodine directly (I) or after a $\mathrm{KOH}$ pre-treatment (K/I). Measurements were taken from water mounts and are indicated as (minimum- $\{\mathrm{X}-\mathrm{SD}\}-\{\mathrm{X}+\mathrm{SD}\}$ (-maximum), where $\mathrm{X}$ is the arithmetic mean and SD the corresponding standard deviation, followed by the number of measurements. The length/breadth ratio of ascospores is indicated as $1 / \mathrm{b}$ and given in the same way. Examined specimens are deposited in the herbaria LE, TNS, and in the herbarium of Pacific Institute of Geography in Vladivostok [designated below as PIG; this acronym is not yet included in Index Herbariorum (Thiers, 2017)].

\section{Dactylospora ANZiae Zhurb., Ezhkin, Skirina \& Y. Ohmura sp. nov. (Fig. 1)}

\section{MycoBank No.: MB 821514}

Lichenicolous fungus. Morphologically similar to Dactylospora rimulicola, but distinguished mainly by the reddish brown vs. brown epihymenium, exciple and hypothecium, paraphyses without dark apical cap, finely verruculose vs. smooth ascospores, and a different host genus, Anzia vs. Lecanora and possibly Pertusaria.

Type: Russia, Sakhalin Region, Kuril Islands, Kunashir Is., near Tret'yakovo, 4358'28.8'N, $145^{\circ} 39^{\prime} 33.2$ "E, elev. $110 \mathrm{~m}$, old growth coniferous-deciduous forest, on Anzia colpota (thallus) growing on bark of Phellodendron sakhalinense, 20.06.2014, A. K. Ezhkin (LE 309623 - holotype).

Etymology - The epithet refers to the host lichen genus Anzia.

Description - Apothecia uniformly blackish, (100-) 150-400(-600) $\mu \mathrm{m}$ diam. (n = 35), with more or less plane disc, usually with distinct 


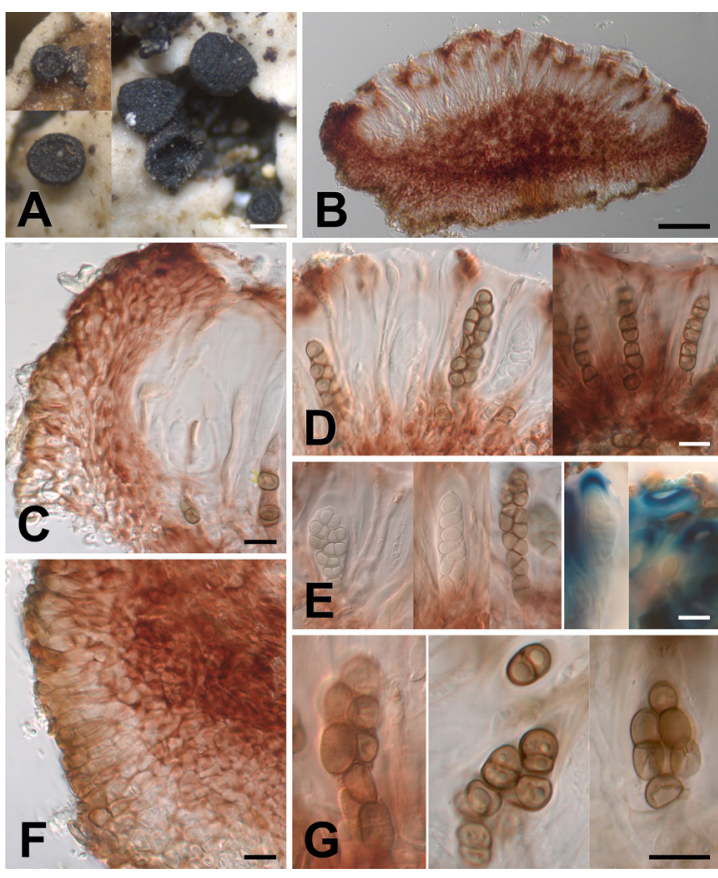

Fig. 1. Dactylospora anziae. A - apothecia (left, LE 309624; right, holotype); B - apothecium in cross section in water (LE 309624); note brown outer rim; C - upper part of lateral exciple in cross section in water (LE 309624); D - epihymenium, hymenium, paraphyses and asci with spores in water (LE 309624); E - asci in water (left, holotype) and I (right, holotype); F - lower part of lateral exciple in cross section in water (LE 309624); G - ascospores in water (holotype, left) and in K (LE 309624, right); note thin verruculose wall. Scale bars: $A=200 \mu \mathrm{m} ; \mathrm{B}=50$ $\mu \mathrm{m}, \mathrm{C}-\mathrm{G}=10 \mu \mathrm{m}$.

margin, sessile, constricted at the base, dispersed to aggregated. Lateral exciple 30-50 $\mu \mathrm{m}$ thick, medium to pale (at the underside of apothecia) reddish brown, $\mathrm{K}+$ brown to greyish brown, with brown, K- outer rim; composed of thick-walled, isodiametric or radially elongated (in the marginal parts) cells. Lower exciple (hypothecium) 80-170 $\mu \mathrm{m}$ tall, medium reddish brown, composed of thick-walled, isodiametric cells. Epihymenium medium reddish brown (pigmentation patchy, amorphous), 5-8 $\mu \mathrm{m}$ tall, $\mathrm{K}+$ brown to greyish brown. Hymenium hyaline or occasionally partly pale reddish brown, 50-60(70) $\mu \mathrm{m}$ tall, I and K/I+ blue or partly red. $\mathrm{Pa}$ - raphyses occasionally branched above, septate, constricted at the septa, 1-2.5(-3.5) $\mu \mathrm{m}$ diam.; apex enlarged, but not capitate, 3-4.5 $\mu \mathrm{m}$ diam., without distinct dark cap. Apothecial sections without blue-green, $\mathrm{K}+$ aeruginose patches. Asci clavate to broadly cylindrical, (42-)44-56(-60) $\times$ (10-)11-15(-17) $\mu \mathrm{m}(\mathrm{n}=15), 8$-spored, covered by a I and $\mathrm{K} / \mathrm{I}+$ blue or partly red gelatinous layer (staining more intense blue at the top). Ascospores oblong, ellipsoid or obovoid, with rounded ends, $(6.3-) 8.9-10.4(-12.3) \times(3.8-) 4.8-$ $6.2(-7.9) \mu \mathrm{m}, 1 / \mathrm{b}=(1.1-) 1.5-1.9(-2.4)(\mathrm{n}=222)$, (0-)1-septate, usually constricted at the septum (sometimes markedly so), initially hyaline, later light olive grey and finally light to medium brown, with finely verruculose wall 0.4-0.7 $\mu \mathrm{m}$ thick, usually with conspicuous guttules (better seen in K), biseriate to diagonally uniseriate in the ascus. Conidiomata not observed.

Distribution and hosts - The new species is known from 17 collections in the Far East of Russia (Jewish Autonomous Region, Khabarovsk Territory, Primorye Territory and Sakhalin Region) and Japan (Hokkaido), growing in coniferous, deciduous or mixed forests on thalli and occasionally apothecia of Anzia colpodes, A. colpota, A. opuntiella and A. stenophylla. Pathogenicity not observed.

Notes - Twenty seven of 40 (68\%) currently known lichenicolous species of Dactylospora are confined to particular host genus, none of them was known to grow on Anzia, Parmeliaceae (Lawrey \& Diederich, 2017). The species of Dactylospora growing on the other members of Parmeliaceae clearly differ from $D$. anziae in the following way: D. allantoidea Alstrup \& D. Hawksw. (reported on Xanthoparmelia pulla) has much larger allantoid ascospores 24.5-28 $\mu m$ long (Alstrup \& Hawksworth, 1990); D. inconspicua Etayo (on Menegazzia spp.) and D. polyspora Triebel (on Protoparmelia spp.) are characterized by polyspored asci (Etayo \& Sancho, 2008; Triebel, 1989).

The other lichenicolous species of Dactylospora with 8-spored asci and 1-septate ascospores of similar size differ from $D$. anziae as follows: D. acarosporae (H. Magn.) Hafellner (reported on Acarospora spp.) is distinguished from the new species by its brown epihymenium and exciple, paraphyses with dark apical caps and narrower ascospores, 8-11 × 3.5-5 $\mu \mathrm{m}$ (Hafellner, 1979); D. aeruginosa Hohlien \& Ihlen (on 
various crustose lichens, also on bark and wood) clearly differs by the presence of violetblue, $\mathrm{K}+$ aeruginose patches in apothecial sections (Ihlen et al., 2004); D. amygdalariae Triebel (on Amygdalaria spp.) has a brown epihymenium and exciple, paraphyses with dark apical caps and narrower ascospores, 7-12 $\times$ 3.5-5.5 $\mu \mathrm{m}$ (Triebel, 1989); D. athallina (Müll. Arg.) Hafellner (on Baeomyces rufus) is distinct by its $\mathrm{K}+$ purple epihymenium and somewhat longer ascospores, 9-14.5 × 4-7 $\mu \mathrm{m}$ (Hafellner, 1979); D. australis Triebel \& Hertel (on species of Lecidea, Paraporpidia, Poeltiaria, Poeltidea, Porpidia, Rimularia and Tremolecia) has a brown epihymenium and exciple, paraphyses with dark apical cap and somewhat longer and narrower ascospores, 7.5-13.5 × 4-6 $\mu \mathrm{m}$ (Triebel, 1989); D. homoclinella (Nyl.) Hafellner (on species of Lecanora and Tephromela) has a brown epihymenium and exciple, paraphyses with dark apical caps and somewhat longer and narrower ascospores, 7.5-12 × 4-6 $\mu \mathrm{m}$ (Hafellner, 1979); D. protothallina (Anzi) Hafellner (on species of Fuscopannaria and Parmeliella) is distinct by a brown epihymenium and exciple and longer ascospores, 9-15 × 4.5-7.5 $\mu \mathrm{m}$ (Hafellner, 1979); D. rimulicola (Müll. Arg.) Hafellner (on species of Lecanora and possibly Pertusaria) differs in having a brown epihymenium, exciple and hypothecium, hyaline hymenium, paraphyses with dark apical caps and smooth ascospores (Hafellner, 1979); D. saxatilis (Schaer.) Hafellner (on species of Ochrolechia and Pertusaria) can be distinguished by the initially immersed apothecia, brown epihymenium and exciple, paraphyses with dark apical caps and longer ascospores, 9-15 × 4.5-7.5 $\mu \mathrm{m}$ (Hafellner, 1979); D. tegularum (Arnold) Hafellner (on Caloplaca spp.) differs in having for the most part immersed apothecia, a brown epihymenium and exciple and paraphyses with dark apical caps (Hafellner, 1979).

\footnotetext{
Additional specimens examined: RUSSIA. Jewish Autonomous Region: Malyi Khingan Range, Bastak Reserve, Mt. Chernukha, 4905'59”N, $133^{\circ} 03^{\prime} 14^{\prime} E$, elev. $590 \mathrm{~m}$, coniferous-deciduous forest, on Anzia colpodes (thallus), 12.08.2002, I. F. Skirina (LE 309628, PIG 24614); Bastak Reserve, $\mathrm{km} 36$ of road from Birobidzhan to Kukan, 49 $03^{\prime} 14^{\prime \prime N}, 133^{\circ} 02^{\prime} 50^{\prime \prime} \mathrm{E}$, elev. $590 \mathrm{~m}$, coniferous-deciduous forest, on A. colpodes (thallus), 13.08.2002, I. F. Skirina \& V. I. Skirin (LE 309629, PIG 14510). Khabarovsk Territory: Sikhote-Alin' Range, near Mukhen, Si River, head-
}

waters of Signal'nyi Creek, $48^{\circ} 11^{\prime} 20^{\prime \prime N}, 136^{\circ} 11^{\prime} 22^{\prime \prime E}$, elev. $100 \mathrm{~m}$, coniferous-deciduous forest, on $A$. stenophylla (thallus), 17.07.1983, I. F. Skirina (LE 309630, PIG 20356); same place, on A. opuntiella (thallus), 17.07.1983, I. F. Skirina (LE 309631, PIG 5871). Primorye Territory: Chernye Mts., Mt. Shapka near Nezhino, 4325'55"N, 13143'09”E, elev. 190 m, oak forest, on A. stenophylla (thallus), 26.06.2009, I. F. Skirina \& F. V. Skirin (LE 309632, PIG 25562); Chernye Mts., Kedrovaya Pad' Reserve, southeastern slope of Gakkelevskiy Ridge, 4306'02”N, 131 $34^{\circ} 06^{\prime}$ E, elev. $300 \mathrm{~m}$, oak forest, on A. colpodes (thallus), 6.10.1954, L. N. Vasil'eva (LE 309633, PIG 13209); same place, on A. colpodes (thallus), 10.07.1999, I. F. Skirina (LE 309634, PIG 34749); Chernye Mts., Kedrovaya Pad' Reserve, Sukhorechenskiy Ridge, $43^{\circ} 05^{\prime} 47^{\prime \prime N}, 131^{\circ} 25^{\prime} 22^{\prime}$ E, elev. $650 \mathrm{~m}$, black fir-spruce forest, on A. colpodes (thallus), 11.07.1999, I. F. Skirina (LE 309635, PIG 34616); Sikhote-Alin' Range, Partizanskiy Ridge, Mt. Lysaya near Binevskoe, headwaters of Elamovskiy Creek, 4314'46”N, 13342'57'E, elev. $750 \mathrm{~m}$, fir-spruce forest, on $A$. colpodes (thallus), 29.08.2001, I. F. Skirina (LE 309636, PIG 30394); Sikhote-Alin' Range, near Valentin, Valentinovka Creek, $43^{\circ} 08^{\prime} 09^{\prime \prime} \mathrm{N}, 134^{\circ} 16^{\prime} 26^{\prime \prime} \mathrm{E}$, elev. $95 \mathrm{~m}$, deciduous forest, on A. stenophylla, 24.08.2008, A. V. Dudnik (LE 309637, PIG 24278); Sikhote-Alin' Range, Ussuriyskiy Reserve, Anikina pad' River, 4340'52'N, 132 29'08'E, elev. $200 \mathrm{~m}$, spruce forest, on A. stenophylla (thallus), 7.06.1974, L. A. Knyazheva (LE 309638, PIG 9772); Ussuriyskiy Reserve, Mironov Creek, 4339'04"N, $132^{\circ} 27^{\prime} 09^{\prime} \mathrm{E}$, elev. $260 \mathrm{~m}$, pine-deciduous forest, on $A$. colpodes (discs of apothecia, thallus), 14.08.1958, N. I. Vokueva (LE 309639, PIG 9760); Sakhalin Region: same place as for the holotype, on A. colpota (discs and margins of apothecia, thallus), 20.06.2014, A. K. Ezhkin (LE 309624); Kuril Islands, Kunashir Is., Prosolovskie springs, $44^{\circ} 19^{\prime} 58.43$ "N, 146¹'14.52"E, elev. $15 \mathrm{~m}$, old growth coniferous-deciduous forest, on A. colpota (thallus), 19.06.2014, A. K. Ezhkin (LE 309625). JAPAN. Hokkaido: Prov. Kushiro, Aikappu, Akkeshi-gun, $43^{\circ} 01^{\prime} \mathrm{N}, 144^{\circ} 50$ 'E, elev. $70 \mathrm{~m}$, deciduous forest dominated by Quercus crispula, Acer mono, and Tilia japonica, on A. colpota (thallus), 8.08.2002, T. Shiba 333 (TNS); Prov. Kushiro, Mt. O-Akan, $43^{\circ} 26^{\prime} \mathrm{N}, 144^{\circ} 08^{\prime} \mathrm{E}$, elev. $460 \mathrm{~m}$, mixed forest dominated by Abies sachalinensis, Picea jezoensis, Magnolia obovata and Quercus crispula, on A. colpota (thallus), 29.08.1965, S. Kurokawa 65634 (TNS).

\section{ACKNOWLEDGEMENTS}

Wolfgang von Brackel and Javier Etayo are thanked for their valuable comments on the manuscript. The study of M. P. Zhurbenko was financially supported by the JSPS Invitation Fellowship for Research in Japan (no. S16173) and the research project of the Komarov Botanical Institute, Russian Academy of Sciences (St. 
Petersburg, Russia) no. 01201255602 . It was carried out using equipment of the Core Facility Center "Cell and Molecular Technologies in Plant Science" of the Komarov Botanical Institute. The study of A. K. Ezhkin was partially supported by the Russian Foundation for Basic Research grant no. 13-05-00544 A.

\section{REFERENCES}

Alstrup, V. \& Hawksworth, D. L. 1990. The lichenicolous fungi of Greenland. Meddelelser om Grønland, Bioscience 31: 1-90.

Etayo, J. 2002. Aportacion al conocimiento de los hongos liquenicolas de Colombia. Bibliotheca Lichenologica 84: 1-154.

Etayo, J. \& Sancho, L. G. 2008. Hongos liquenícolas del Sur de Sudamérica, especialmente de Isla Navarino (Chile). Bibliotheca Lichenologica 98: 1-302.

Hafellner, J. 1979. Karschia. Revision einer Sammelgattung an der Grenze von lichenisierten und nichlichenisierten Ascomyceten. Beiheft zur Nova Hedwigia 62: 1-248.
Hafellner, J. 2004. Dactylospora. In: Nash III, T. H., Ryan, B. D., Diederich, P., Gries, C., Bungartz, F. (eds). Lichen Flora of the Greater Sonoran Desert Region, Vol. 2. Lichens Unlimited, Arizona State University, Tempe, Arizona, pp. 645-648.

Ihlen, P. G., Holien, H. \& Tønsberg, T. 2004. Two new species of Dactylospora (Dactylosporaceae, Lecanorales), with a key to the known species in Scandinavia. The Bryologist 107: 357-362. https://doi.org/10.1639/00072745(2004)107[0357:TNSODD]2.0.CO;2

Lawrey, J. D. \& Diederich, P. 2017. Lichenicolous fungi - worldwide checklist, including isolated cultures and sequences available. URL: http:/ / www.lichenicolous.net [accessed 24.05.2017].

Thiers, B. 2017. Index Herbariorum: A global directory of public herbaria and associated staff. New York Botanical Garden's Virtual Herbarium. http://sweetgum.nybg.org/science/ih/ [accessed 24.05.2017].

Triebel, D. 1989. Lecideicole Ascomyceten. Eine Revision der obligat lichenicolen Ascomyceten auf lecideoiden Flechten. Bibliotheca Lichenologica 35: 1-278. 